\title{
DEVELOPMENT AND SECURITY - GEOPOLITICAL ASPECTS OF DEMOGRAPHIC CHANGES IN SOUTH-EASTERN SERBIA
}

The paper discusses the implications of demographic changes in South East Serbia on development, security and stability, that is, instability in Serbia and the Balkans. These demographic changes are conditioned by the process of transition, more precisely by the sub-processes that are its integral part, among which the de-industrialization and the privately executed privatization are the most influential in the negative sense. In a short time, the applications of these concepts of development have led to the economic devastation of Serbia, the impoverishment of its population and the deepening of regional disproportions that have promoted South Eastern Serbia as it's economically and demographically most vulnerable parts. The focus of the analysis is on the processes of natural and mechanical population movement in the border municipalities of South Eastern Serbia (migration, aging and depopulation), with a special emphasis on their influence on the development of these regions and their geopolitical stability and prospects. The author points out the need to redefine and adopt the strategy of balanced regional development in Serbia that would reformulate the development policy of the border municipalities through priority goals, preventing the demographic emptying and encouraging the economic development of this geo-space and at the same time, preserving the geostrategic demographic balance as a condition of permanent geopolitical stability.

Keywords: demographic change, South-Eastern Serbia, regional development, geopolitical stability, security.

Faculty of Law and Business Studies „dr Lazar Vrkatić, Novi Sad, Union University, Belgrade, Serbia; ibozicmiljkovic@gmail.com 


\section{Introduction}

Recent economic and demographic history of the region of South Eastern Serbia, written in the last quarter of the century, is the result of the major economic losses and to some extent, economic and demographic devastation. Deindustrialization is the main feature of the economy during that period and the decline in population is a basic demographic trend. South - Eastern Serbia, once economically prosperous region, primarily oriented towards agricultural production with a developed industry that employed tens of thousands of people, compared with other regions in Serbia, is at the very bottom of the development scale today, and at the very top of unemployment, poverty and demographic problems. Negative demographic trends in South Eastern Serbia were latently present throughout the second half of the 20th century. During the 90s their full momentum appeared when the process of transition that initiated the deepening of the economic expansion within Serbia began. In this respect, a clear division was made towards the Center (Belgrade and Vojvodina) on one hand, and the periphery of the underdeveloped South-Eastern Serbia on the other.

Having been created for decades, regional disparities in Serbia are multilayered and present both throughout the region and within the region itself. The direct consequences of these disparities are the three types of migration: reversible migration from the village-city that has been present in recent years, not as a result of improving the living conditions in the countryside, but as the consequence of the economic crisis and the loss of jobs in cities, the massive outflow of the population from the economically devastated areas of SouthEastern Serbia towards the north and the migration of the working population to the rest of the world. The absence of an adequate regional development policy during the first decade of the 21st century contributed to the continual poverty and economic decline of the region of South-Eastern Serbia. The main features of this region today are: depopulation and aging of the population, unemployment and low level of diversification of economic activities, agriculture as a dominant but low productive activity, poverty, low level of education of the population, inadequate infrastructure (lack of paved roads, drinking water, etc.).

Stopping negative demographic trends in the region of South-Eastern Serbia, which synthetically reflect its economic problems, presupposes numerous activities in the direction of revitalizing the economic potentials and production capacities of the area. In designing future coordinates of a more balanced regional development, the Republic of Serbia should pay special attention to the regional component of the policy of reindustrialization. The region of SouthEastern Serbia has the conditions to include its potentials in this process, with full respect for the contemporary global trends in which it will be implemented. The ultimate goal should be to raise the level of its economic development; on the contrary, it is on its way to losing its population, thus jeopardizing its future. 


\section{Geopolitical position and demographic picture of South-Eastern Serbia}

South-Eastern Serbia in a geopolitical view, resembles the Balkan crossroads in many respects, a crossroad between the east and west, north and south. For centuries, it was a geo-space with the arch of different civilizations and cultures, it has crossed paths of traders and warriors. Therefore, it is the region of encounter, touch, dialogue and conflict, as well as the interweaving of different civilizations. In geostrategic terms, it represents Huntington's thesis on the zones of politically imperfect boundaries, conflict potential, and transition choices. It is exactly the history of the 20th century, even the beginning of the 21st century hat most clearly illustrates the importance and role of this region in geo-strategic re-engagements, political conflicts, and transition challenges. Also, the latest large migrations of the population from the Near and Middle East (Syria, Iran, Afghanistan ...), are just beginning talking about the transit character of this region and its vulnerability in every major breakthrough moment in the history of the Balkans, Europe and the world. Researching the population of a region and the country, its structure and dynamics is crucial for understanding not only the demographic vitality of the people, but also its defense capabilities. Bearing in mind the geopolitical position of Serbia, and especially the South-Eastern Serbia region, it is necessary to investigate both the developmental and the security aspects of demographic change, as well as to initiate action research in order to build a long-term program of revitalization of this region through a policy of balanced regional development, a new economic policy towards agriculture and the village, particularly regarding the development of the border municipalities of South-Eastern Serbia.

The region of the South-Eastern Serbia, in geographical sense, consists of seven districts: Nišavski, Pirotski, Toplički, Jablanički, Pčinjski, Borski and Zaječarski. It is limited to the state border with Bulgaria and Macedonia, the administrative line with Kosovo and Metohija and the mountain ranges of Stara Planina and Kopanonik, which are geographically separated from the rest of the Serbia. It is located in the South Morava and Timok river basins and has a very favorable geographical position - it is located at the intersection of all major European transport corridors and is connected with its surroundings. It administratively includes 37 municipalities and cities, more than half of which belong to the group of economically underdeveloped. In its northern central part, Niš is the largest city in the region and the regional center. 
Figure 1. Map of South-Eastern Serbia

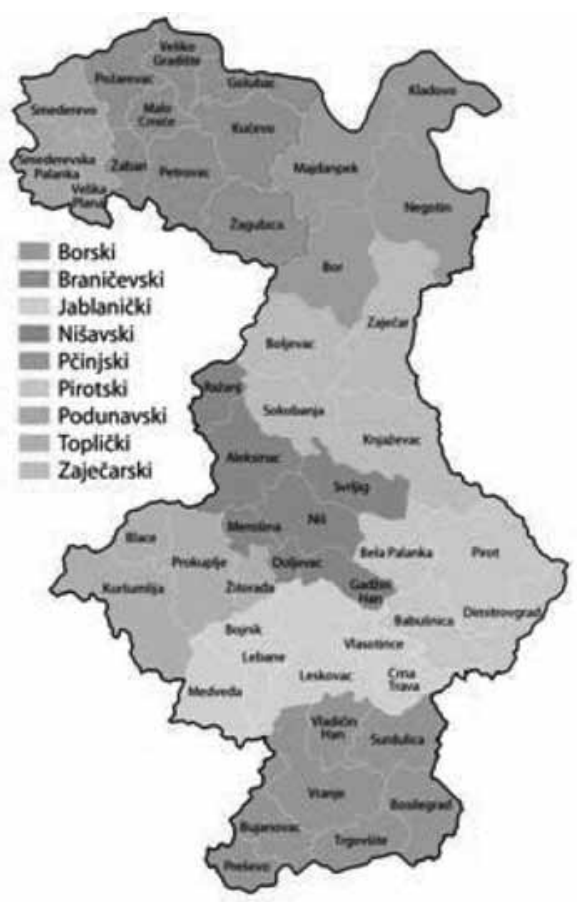

Source: http://www.lokalnirazvoj.org/sr/books/details/23

The contemporary demographic characteristics and demographic trends of the region of South Eastern Serbia are the results of its historical and economic heritage. Historically, the region experienced the largest and most intensive economic and demographic changes in the period after the Second World War. During this period there is accelerated industrialization, which determines the overall dynamics of economic development of the region of South-Eastern Serbia, significantly changing its economic and social structure of the population. The industrialization process had the greatest positive effects on the region of SouthEastern Serbia between year 1960 and 1980. During that time, the region of South Eastern Serbia kept developing and acquiring all the features of the urban area. ${ }^{1}$ Changes in the economic and urban structure of the population were conditioned by the migration of the population within the region, primarily in relation from the village to the city. Migrations to other parts of former Yugoslavia were present to a lesser extent, while migrations abroad were determined by specific occupations

$1 \quad$ More details: Božić, M. i Golubović, S. (2012): Ekonomska uslovljenost migracije stanovništva u regionu jugoistočne Srbije, u: Stanovništvo jugoistočne Srbije: uticaj demografskih promena u jugoistočnoj Srbiji na društveni razvoj i bezbednost, Centar za naučna istraživanja SANU i Univerzitet u Nišu, Niš, p. 43 - 56. 
such as construction and various types of crafts. In this period, the demographic transformation of the region of South-Eastern Serbia was conditioned by the positive effects of industrialization in the field of employment and the fact that the population in this area had an economic and with it other perspectives. ${ }^{2}$ Positive economic and demographic trends stimulated by industrialization started changing in the 1980s, and the break-up of Yugoslavia and the move to the transition process, a long period of degradation of the economic development, economic poverty and demographic devastation of the whole of Serbia began. These processes are strongest in the region of South-Eastern Serbia, whose basic characteristics today are: unemployment, poverty and a large outflow of the working-age population. ${ }^{3}$ The current situation is the result of the long-term absence of an adequate regional development policy at the level of the whole of Serbia and insufficient investment activity in its poorer parts.

Table 1. Comparative overview of the number of inhabitants in the period from 1948 to the last census of population in 2011

\begin{tabular}{|l|c|c|c|c|c|c|c|c|}
\hline & 1948. & 1953. & 1961. & 1971. & 1981. & 1991. & 2002. & 2011. \\
\hline Serbia North & 2.274 .602 & 2.430 .477 & 2.797 .161 & 3.161 .920 & 3.504 .855 & 3.616 .115 & 3.608 .116 & 3.591 .249 \\
\hline Vojvodina & 1.640 .599 & 1.698 .640 & 1.854 .971 & 1.952 .560 & 2.034 .782 & 2.013 .889 & 2.098 .779 & 1.931 .809 \\
\hline Belgrade & 634.003 & 731.837 & 942.190 & 1.209 .360 & 1.470 .073 & 1.602 .226 & 1.638 .643 & 1.659 .440 \\
\hline Podunavljedistrict & 153.039 & 164.975 & 180.122 & 197.205 & 220.425 & 226.089 & 209.987 & 199.395 \\
\hline Bordistrict & 144.049 & 151.973 & 160.096 & 175.848 & 180.463 & 178.718 & 146.551 & 124.992 \\
\hline Braničevodistrict & 246.859 & 259.329 & 263.780 & 263.466 & 264.182 & 253.992 & 200.806 & 183.625 \\
\hline Zaječar district & 173.603 & 177.332 & 178.623 & 172.424 & 170.682 & 158.131 & 137.561 & 119.967 \\
\hline Nišava district & 283.842 & 303.482 & 327.367 & 363.292 & 394.110 & 396.043 & 391.932 & 363.319 \\
\hline Toplica district & 141.502 & 149.421 & 141.141 & 129.542 & 121.933 & 111.813 & 105.208 & 91.754 \\
\hline Pirotdistrict & 160.285 & 157.360 & 145.789 & 136.008 & 127.427 & 116.926 & 106.815 & 92.479 \\
\hline Jablanica district & 231.280 & 244.128 & 254.855 & 260.982 & 262.531 & 255.011 & 247.834 & 216.304 \\
\hline Pčinja district & 209.232 & 220.910 & 222.520 & 230.373 & 238.753 & 243.529 & 255.500 & 159.081 \\
\hline
\end{tabular}

Source: popis2011.stat.rs/?page, $\mathrm{id}=2162$

In the period from 1963 to 1989 , the secondary sector of southeastern Serbia, which is the backbone of industry, recorded annual growth of employment of 3,6\%, which was more than the recorded growth in Serbia as a whole of 3.1\%. In the districts (areas), this growth was: Nisava District 2.6\%, Jablanica 3.3\%, Pirot 4.7\%, Pcinja 5.1\% and Toplica District 4.6\%.(Krstić, V. (2007):Stanovništvo jugoistočne Srbije, Zavod za urbanizam, Niš, 349).

3 In the period 1960-1980, most emigrants were poorely educated and went abroad mainly through international bilateral employment agreements. (Grečić, V. (1998) Jugoslovenske spoljne migracije - analitičke osnove za utvrđivanje politike SR Jugoslavije u oblasti spoljnih migracija. Beograd: Savezno ministarstvo za rad, zdravstvo i socijalnu politiku, Beograd 28). Since the early 1990s, the level of education of Serbian emigrants has increased significantly, and today, a large proportion of this structure involves highly educated staff (doctors, engineers, scientists and researchers).More details: Kupiszewski M, Kupiszewska, D, Nikitović, V (2010): Uticaj demografskih i migracionih tokova na Srbiju, Međunarodna organizacija za migracije, Beograd. 
According to the 2011 Population Census, Serbia is at the threshold of a demographic catastrophe. Such a situation is the result of a long-standing unenviable economic situation, unemployment, low and irregular income, an uncertain future in terms of economic stability and the lack of employment prospects and the economic valorization of knowledge and skills, especially for the young people. All of the above presents a major obstacle towards the creation of a family and its expansion, resulting in a long-term decline in birth rates and a negative rate of natural increase. These consequences of the general demographic situation are much more pronounced in the region of South-Eastern Serbia, which in the previous period of transition, in terms of economic development, suffered the most damage, and whose basic characteristics todayare depopulation and aging of the population.

Table 2. Increase / decrease in the number of inhabitants per district between the two censuses

\begin{tabular}{|l|c|c|c|c|c|}
\hline \multicolumn{1}{|c|}{ District } & $1961 / 1971$ & $1971 / 1981$ & $1981 / 1991$ & $1991 / 2002$ & $2002 / 2011$ \\
\hline Podunavlje & 17.083 & 23.220 & 5.664 & -16.102 & -10.592 \\
\hline Bor & 15.752 & 4.615 & -1.745 & -32.167 & -21.559 \\
\hline Braničevo & -314 & 716 & -10.190 & -53.186 & -17.181 \\
\hline Zaječar & -6.199 & -1.742 & -12.551 & -20.570 & -17.594 \\
\hline Nišava & 35.925 & 30.818 & 1.933 & 5.632 & -21.340 \\
\hline Toplica & -11.599 & -7.609 & -10.120 & -2.403 & -16.408 \\
\hline Pirot & -9.789 & -8.581 & -10.501 & -9.820 & -13.759 \\
\hline Jablanica & 6.127 & 1.549 & -7.520 & -7.009 & -25.411 \\
\hline Pčinja & 7.853 & 8.380 & 4.776 & -4.879 & -8.679 \\
\hline
\end{tabular}

Source: Calculated on the census data base

Data on the decrease in the number of inhabitants in South-Eastern Serbia and the districts in its composition have shown all the dramatic nature of this process in the last two decades. Between the last two lists, all districts, even Nisavski, recorded a decrease in the number of inhabitants. The Toplica and Pirot districts have realized the continuity of this decline since the early 1960s. Since the 1980s, Braničevski and Jablanički joined them, and since the 1990s, the Danube and Pčinja districts have followed the same trend. The reasons for these trends in population movements should be sought in two factors: the first is the reduction of the natural increase of the population, and the second is the emigration of the population to other parts of Serbia and abroad. Both of these processes are associated with the economic conditions and the economic 
development of the region. ${ }^{4}$ Its economic misery since the end of the 1980s has made this region less promising for people's lives. Unemployment, poverty, poor economic and social infrastructure have led to an increase in the emigration of young people from the region, while the part of the young population that has stayed is finding it increasingly difficult to create a family and expand. As a consequence, we have an aging population, disappearance of a large number of rural settlements, and even the reduction of the number of inhabitants in some smaller cities in the region. ${ }^{5}$ Although this process is expressed throughout Serbia, it is particularly typical of its South-Eastern part. From year to year, an increasing number of settlements in the municipalities of Kuršumlija, Lebane, Surdulica, Bosilegrad, Crna Trava, Pirot, Babušnica, etc. are being extinguished. However, it is mainly the mountain villages, often without basic economic and social infrastructure, the settlements that were created in the 19th century and earlier, that cannot survive in the new conditions, primarily for economic reasons. The villages along the border and across mountains vanish first. Resistant settlements are those that are gravitating towards cities, with which they are usually functionally related. ${ }^{6}$

\section{Security aspects of demographic flows in the South-eastern Serbia}

Strong migration process and especially high depopulation and senility of population of rural settlements in border municipalities of South-Eastern Serbia are limiting factors against faster economic development with negative consequences for the security capability of this region. ${ }^{7}$ Regardless of the

$4 \quad$ Božić Miljković, I (2013):Reindustrijalizacija kao uslov zaustavljanja demografskog pražnjenja jugoistočne Srbije, Ekonomski vidici, vol.18, br. 2-3, Beograd, str. 315 -327.

5 Reduction of the number of inhabitants in rural, even smaller towns, settlements - until complete demographic emptying and thedisappearance of a large number of them, is a general trend in Serbia. (Panev, G. i Marinković, I. (2012): Prvi rezultati popisa stanovništva 2011. s posebnim osvrtom na promenu broja stanovnika jugoistočne Srbije, u zborniku radova Stanovništvo jugoistočne Srbije: uticaj demografskih promena u jugoistočnoj Srbiji na društveni razvoj i bezbednost, Centar za naučna istraživanja SANU i Univerzitet u Nišu, Niš, 22 - 43). According to the findings of this research, between two censuses of population in 2002-2011, in Serbia, 91\% of the settlements (excluding the municipalities of Bujanovac and Presevo and treating Belgrade and Niš as unique settlements) resulted in a decrease in the number of inhabitants. In only 345 settlements in Serbia there was an increase in the number of inhabitants in this period.

6 Babović, S., Obradović Lović, S., Prigunova, I. (2016):Depopulation of Villages in Southeastern Serbia as Hindrance to Economic Development, Journal of the Geographical Institute 'Jovan Cvijic'. Belgrade, Vol. 66 Issue 1, p.68.

7 The bordering area of south-east Serbia includes the territory of nine municipalities along the border with Bulgaria and Macedonia. In this area, the area of $4850 \mathrm{~km} 2,(5.5 \%$ of the territory of Serbia)there are 400 settlements. (Golubović, N., Đorđević, D. (2012): Sociodemografski procesi u pograničnim opštinama Jugoistočne Srbije, U Lj. R. Mitrović 
significance of the new technologies towards strengthening the security of a country, it is a true fact that there is no state, nor its regions without population. This, in turn, means that it is necessary to encourage, by planning measures, keeping the population within the border, in order to have a sustainable demographic balance of the living forces in this geo-space. The current situation of a demographic black hole leaves this area porous and unprotected. It is worth pointing out that the borders of a country are not only protected by professional soldiers and its foreign policy of peace, but also by a balanced and well-distributed composition of the population, which represents a kind of demographic military landscape, a living obstacle to eventual aggression against our country, its sovereignty and territorial integrity. ${ }^{8}$ Demographic trends, especially the internal and external migrations of the population, have devastated this geo-space: the exodus of entire settlements along the South-Eastern border of Serbia. Also, the current demographic trends - the demographic boom of Albanians from Kosovo and Metohije and the large population of the Middle and Middle East and North Africa immigrants along the Balkan route - carry with them the security risks that must be compromised in the national security policy of the country. These processes are not current and short-term, but long-term, because they are conditioned by the broad geopolitical context, which in turn is conditioned by the geostrategic engineering of the great powers, above all the neo-imperial aspirations of large-scale capital to re-colonizing the world and transforming the global geopolitical map with the aim of putting under control the capital resources (water, oil, gas, ore and ecologically pure zones).

In this context of the consideration of the geopolitical aspects of the security of Serbia and the Balkans, it should be noted that this region is still far from peace and stability. This region is somewhat pacified by the Euro-Atlantic processes, but the global strategy of NATO's expansion to the East certainly introduces the world to new uncertainties, as well as conflicts with far-reaching consequences. The pressure exerted on Serbia to deny military neutrality is apart of the very engineering of the forces of the New World Order. Therefore, in the policy of national security, one should remain consistent and conduct an active balanced foreign policy of peace, strategic partnership and cooperation with neighbors. Throughout its history Serbia has never been an aggressor and has always fought defensive wars. Therefor it must follow this strategy of defense of national sovereignty in the future. By developing its economic potential, demographic order, and by strengthening its defense capabilities, it can preserve its external

(ur.),Stanovništvo jugoistočne Srbije: uticaj demografskih promena u jugoistočnoj Srbiji na društveni razvoj i bezbednost, Centar za naučnoistraživački rad SANU i Univerzitet u Nišu, Niš, 215-216). According to the 2002 census, 610,149 inhabitants lived in the border region of south-eastern Serbia, and according to the 2011 census, there were 467,864 inhabitants there.

8 Stojković, M. (1991):Uticaj odnosa sa susednim zemljama na pogranične krajeve Srbije, Geografski problemi pograničnih krajeva Srbije. Beograd: Geografski fakultet PMF. 
and internal freedom. A nation that does not obey other nations, but seeks to build bridges of cooperation and friendship with them, is free and capable of facing all the possible challenges in the future.

\section{Regional development policy: consequences for South-eastern Serbia}

Economic stability is a main prerequisite for the achievement of the goals of national security policy. The priority of economic policy is sustainable development with a tendency of long-term expansive development and high rate of economic growth, as a significant measure of support to strengthen the economic stability of the state. ${ }^{9}$ Economic development of Serbia is significantly conditioned by external factors: there is the need for continuous fulfillment of conditions related to the EU accession and integration processes and active participation in the international economy and regional arrangements. In this context, regionalization issues, regional development policy and regional policy are among the most complex issues of economic theory and practice. The complexity and multidimensionality of these problems are determined by the strong influence of geographical, historical and political factors, while their resolution is conditioned by professional knowledge, learning from past experience and implementation of successful foreign experiences. In Serbia, in the last quarter of the century, the issue of regional development was neglected, that is, it was not approached as an integral part of overall socio-economic development. As a result, there have been major interregional mismatches that limit the possibilities of development and separation from the economic and social margins. ${ }^{10}$

9 Economic development of Serbia is significantly conditioned by external factors which necessitates the need for continuous fulfillment of conditions related to the EU accession and integration processes and active participation in the international economy and regional arrangements.(Serbia, Foreign Policy and National Security Yearbook Vol.1, Strategic Information and Developments, International Business Publications, USA, Washington DC, USA-Serbia, 2014, 96).

10 Regarding the balanced regional development in Serbia, little has been done, despite the existence of extensive studies and strategies written on this topic. "The process of regionalization of Serbia was initiated by the adoption of the Strategy on Regional Development in 2007 and the Law on Regional Development in 2009. The Strategy of Regional Development of Serbia for the period from 2007 to 2012 is the first strategic development document in the field of regional development, which, in a consistent and comprehensive manner, defines the basic development priorities of the regional development of the country and the ways of its realization in the coming years." (Đorđević, M., Obradović, S., Lojanica, N. (2015):Komparativna analiza regionalne razvijenosti Šumadijskog $i$ ostalih regiona $u$ Republici Srbiji, zbornik radova: Stanje i perspektive ekonomskog razvoja grada Kragujevca, Ekonomski fakultet Univerziteta u Kragujevcu, Kragujevac, 55). 
In the wider region of South-Eastern Serbia, Niš, Leskovac, Vranje, Zajecar, Bor, Prokuplje and Pirot are distinguished as important economic, cultural, political and administrative centers. All of them have been economically, culturally degraded and devastated in the past 25 years. UN sanctions and bombardment by the NATO forces, as well as the policy of implementing the transition process based on the Washington Consensus postulates, have devastated many economic potentials, economic capacities and infrastructure facilities. ${ }^{11}$ They are not able to provide free social reproduction today, nor activate economic and cultural resources without foreign financial assistance or foreign direct investment. ${ }^{12}$ Foreign direct investments, which were implemented in Serbia after 2000, were sufficient to stimulate economic development and reduce regional disparities that were not expressed to the extent they are today. However, a small dispersion of these investments at the regional level has caused regional disparities to become even more pronounced and to create insurmountable developmental differences among the regions. Increased investor interest in investments in major cities and regions has led to investment concentrating in these areas, while poorer regions have been neglected and exposed to further economic decline. ${ }^{13}$ Former models of economic development in Serbia have largely been based on sectorial priorities and policies, where the policy of regional development and long-term regional planning did not get a welldeserved place, while the measures undertaken in this domain were periodic, non-harmonized and focused on short-term incentives for the development of underdeveloped areas. That is why their positive effects are missing, and the illustration of regional differences is given in the following picture through a comparative overview of the number of enterprises, the number of employees and gross added value. ${ }^{14}$

11 According to the first National Report on social inclusion and poverty reduction of the Government, poor population living in underdeveloped areas. A quarter of the total poor Serbian population lives in Southern Serbia, (Lukić, V. (2013):Population Trends in Serbia and the Implications for Settlement System, Forum geografic. Studii și cercetări de geografie și protecția mediului Volume XII(1) 72).

12 Butigan, V. (2004):Sociokulturne odlike regiona u jugoistočnoj Srbiji, zbornik radova: Kvalitet međuetničkih odnosa, svest o regionalnom identitetu i mogućnosti saradnje i integracije na Balkanu, Filozofski fakultet Niš, Institut za sociologiju, str.181-188

13 Božić Miljković, I (2014):Investicije i investiciona politika: konsekvence na odliv stanovništva iz nerazvijenih područja Srbije, zbornik radova: Stanovništvo jugoistočne Srbije: regionalne disproporcije u razvoju Srbije, migracije i demografska reprodukcija, Centar za naučnoistraživački rad SANU Univerziteta u Nišu, Filozofski fakultet Univerziteta u Nišu, str. 31-54

14 Gross value added is the total output minus intermediate consumption. 
Figure 2. Participation of enterprises, employees and gross value added in the Serbian economy

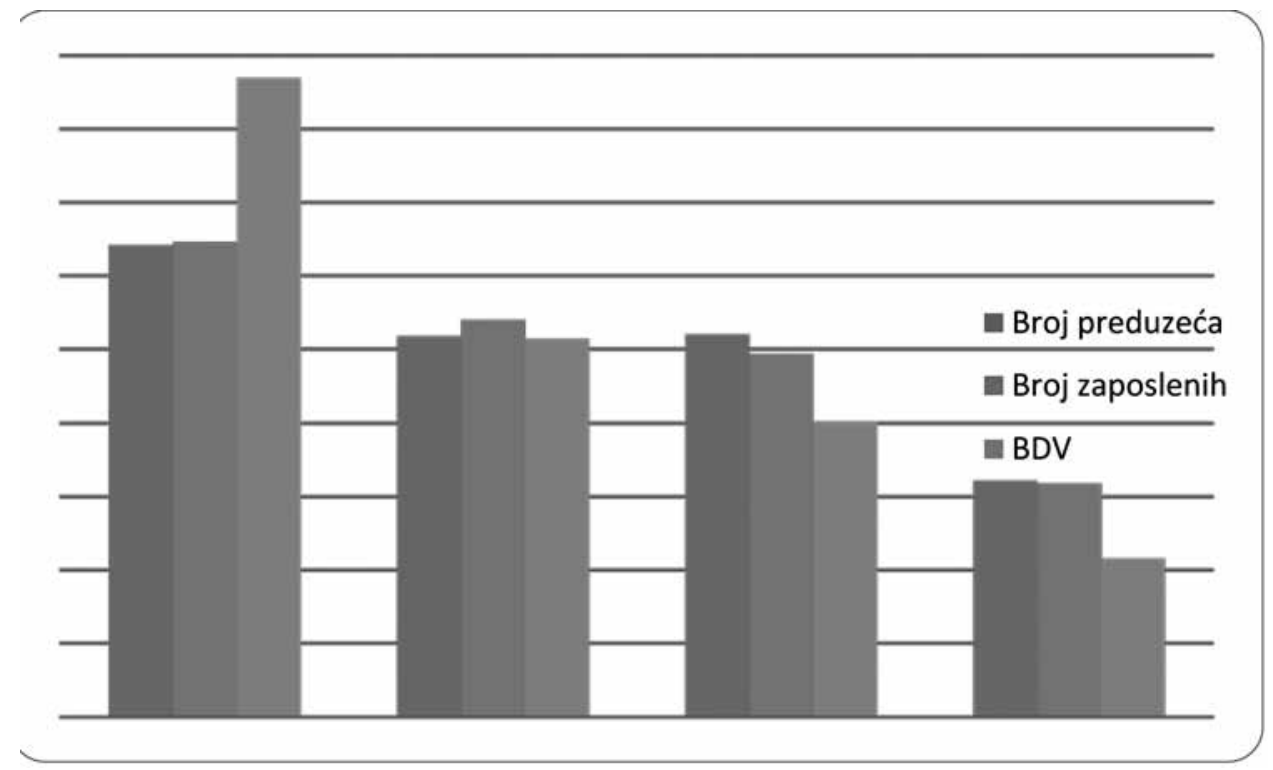

Source: Ministry of the Republic of Serbia, Report on Small and Medium Enterprises and Entrepreneurship for 2015, Belgrade, November 2016, p. 17-18

Obviously, the current regional development policy in Serbia, especially in the period after 2000, not only failed to deliver results, but also strengthened sub-development / underdevelopment and lagging behind of most of the municipalities and regions in Serbia in relation to Belgrade and Vojvodina. To stop the current negative processes, it is necessary to make a radical break with the neoliberal strategy of the global social development. ${ }^{15}$ Unless the issue is approached in such a way, it is certain that regional disparities in Serbia will take on forms of ethno-political and geopolitical conflicts. Demographic and economic problems are now in the foreground, but if such a trend continues, Serbia may also expect political problems of integration of certain regions into the global system in the future. Solutions need to be sought in the new regional development strategy, whose main goals and principles are: sustainable development, raising regional competitiveness, reducing regional disparities and poverty, stopping negative demographic trends, continuing the decentralization process and strengthening local / regional self-government, economic integration

15 Without this, Serbia will remain in a vicious circle of poverty and lumpenism.(Mitrović, $\mathrm{Lj}$. (2014):Uticaj regionalnih nejednakosti u Srbiji na tokove migracija i demografske promene u jugoistočnoj Srbiji, zbornik radova: Stanovništvo jugoistočne Srbije: regionalne disproporcije u razvoju Srbije, migracije i demografska reprodukcija, Centar za naučnoistraživački rad SANU Univerziteta u Nišu, Filozofski fakultet Univerziteta u Nišu, Niš 9-30). 
of the Serbian community and AP Kosovo and Metohija, and the construction of institutional regional infrastructure. ${ }^{16}$

\section{Conclusion}

Demographic changes are an important social phenomenon thatcreates a force of a country, causes its geopolitical stability, economic development and security, and determines its position in international relations. Due to the general trend of negative demographic changes, which is reflected in the decline of the birth rates and large waves of migration of the population from some countries and parts of the world, demographic changes have become the focus of interest in a range of social sciences in recent years: politics, demography, economics and sociology. The problem of demographic change is particularly pronounced in those parts of the world that have suffered strong political changes, war destruction and secession, as well as the economic transition in the process of globalization. One of these areas is that of South- Eastern Serbia. The consequences of the historical circumstances, as well as of the current global processes in which South-Eastern Serbia is necessarily included are huge and far-reaching, and are reflected in the continuous demographic emptying of this area that has been going on for decades. The current regional development policies implemented in Serbia are aimed at improving the economic conditions of the lives of the population in its southeastern part and preventing large waves of economic migration towards major cities of Serbia or abroad. However, more significant results of this plan have not been achieved. Today, the area of south-eastern Serbia, after almost three decades of economic transition, is characterized by: low economic activity, high unemployment, low standard of living, depopulation and aging of the population. The consequences of this area, based on demographic emptiness now, are high and are mainly related to its economic and infrastructural decline and backwardness in cultural development and quality of life in relation to the rest of Serbia and Europe. In the future, these consequences could be even greater, given the fact that many villages in the border belt of South-Eastern Serbia have remained without the young population or have been completely devastated, which could jeopardize the security aspect, that is, the security capability of this area and its territorial integrity and sovereignty. Preserving the population in South-Eastern Serbia, especially in its border area, depends on a more active approach of the state and the local self-governments towards solving this problem. Making a decision by the state to divert a portion of foreign direct investment into this area and thereby encouraging the employment of the population can contribute to improving the demographic situation with positive

16 Jakupi, E. (2013):Izazovi regionalne politike u Srbiji, zbornik radova: Regionalni razvoj i demografski tokovi zemalja jugoistočne Evrope, Ekonomski fakultet Niš, str. 17-30. 
effects that can be seen in the short term. The correction of the demographic balance of South-Eastern Serbia and especially its borderline-work, implies the adoption and implementation of new state strategies for regional development and new planning measures that will be tailored to the European experience, in respect to the specificities of this area.

The absence of an adequate regional development policy in Serbia since the 1990s to the present day and disproportion in the investment activity, have led to a large and growing regional disparities and the demographic emptying of the poorer regions. Particularly affected by these processes is the region of South-Eastern Serbia, especially its border parts, characterized by low economic activity, poverty, high unemployment, depopulation and aging of the population. In addition to the lack of prospects in the economic and developmental sense, demographic emptying has a long-term impact on the security stability of the South-Eastern Serbia and the Balkans. In order to stop the demographic emptying of this devastated region and re-establish the development and security balance on the level of the entire state, Serbia needs a new, rational and democratic framework, a regional policy model that will function:

a) the liberation and further development of the economic potential of the country, with a special emphasis on the development of villages and agriculture;

b) strengthening of local self-government and building of the participatory democracy;

c) democratic integration of a multi-ethnic Serbian society;

d) strengthening of its security potentials, territorial integrity, peace and stability in the wider region.

Serbia can and must abandon the existing bureaucratic mechanisms of centralizing power and strengthening control by developing democracy and a new order of freedom. Addressing the problems of regional disparities depends to a large extent on the active approach of states and local self-governments. The reorientation of a part of the investments in the economically underdeveloped areas will contribute to the development and security potential of Serbia in the future and prevent extremely undesirable demographic flows. Increasing the economic activity of the population, through various forms of employment and professional engagement, is just one of the segments of the action on demographic trends that can give positive effects in the short term. Long-term measures that would contribute to a positive change in the demographic situation in Serbia are an increase in the fertility rate and the establishment of a stable social protection policy based on the reputation of the countries of the European Union. 


\section{Literature}

- Babović Stefana, Obradović Lović Suzana, Prigunova Irina (2016): Depopulation of Villages in South-eastern Serbia as Hindrance to Economic Development, Journal of the Geographical Institute 'Jovan Cvijic'. Belgrade, Vol. 66(1), p61-74.

- Božić Miljković Ivana (2013): Reindustrijalizacija kao uslov zaustavljanja demografskog pražnjenja jugoistočne Srbije, Ekonomski vidici, vol.18, br. 2-3: $315-327$.

- Božić Miljković Ivana (2014): Investicije i investiciona politika: konsekvence na odliv stanovništva iz nerazvijenih područja Srbije, U Ljubiša Mitrović (prir.)Stanovništvo jugoistočne Srbije: regionalne disproporcije u razvoju Srbije, migracije i demografska reprodukcija, (str. 31-54), Niš: Centar za naučnoistraživački rad SANU Univerziteta u Nišu i Filozofski fakultet.

- Božić Milorad, Golubović Srđan (2012):Ekonomska uslovljenost migracije stanovništva u regionu jugoistočne Srbije, (str. 43-56) U Ljubiša Mitrović (prir.)Stanovništvo jugoistočne Srbije: uticaj demografskih promena u jugoistočnoj Srbiji na društveni razvoj i bezbednost, Niš: Centar za naučna istraživanja SANU i Univerzitet u Nišu.

- Butigan Vjekoslav (2004): Sociokulturne odlike regiona u jugoistočnoj Srbiji, $\mathrm{U}$ : Kvalitet međuetničkih odnosa, svest o regionalnom identitetu i mogućnosti saradnje i integracije na Balkanu, (str. 181-188), Niš: Filozofski fakultet Niš, Institut za sociološka istraživanja.

- Đorđević Miroslav, Obradović Saša, Lojanica Nemanja (2015): Komparativna analiza regionalne razvijenosti Šumadijskog i ostalih regiona u Republici Srbiji, U: Stanje i perspektive ekonomskog razvoja grada Kragujevca, (str. 53-60), Ekonomski fakultet Univerziteta u Kragujevcu.

- Golubović Ninoslav, Đorđević, Dragoljub (2012): Sociodemografski procesi u pograničnim opštinama Jugoistočne srbije, U LjubišaMitrović (ur.),Stanovništvo jugoistočne Srbije: uticaj demografskih promena u jugoistočnoj Srbiji na društveni razvoj i bezbednost, str.215-227. Niš: Centar za naučnoistraživačkirad SANU i Univerzitet u Nišu.

- Grečić Vladimir (1998):Jugoslovenske spoljne migracije - analitičke osnove za utvrđivanje politike SR Jugoslavije u oblasti spoljnih migracija. Beograd: Savezno ministarstvo za rad, zdravstvo i socijalnu politiku

- Jakupi Edvard (2013): Izazovi regionalne politike u Srbiji, U: Regionalni razvoj i demografski tokovi zemalja jugoistočne Evrope, (str. 17-30) Univerzitet u Nišu, Ekonomski fakultet.

- Krstić Vojislav (2007):Stanovništvo jugoistočne Srbije, Zavod za urbanizam, Niš. 
- Kupiszewski Marek, Kupiszewska Dorota, Nikitović, Vladimir (2010):Uticaj demografskih i migracionih tokova na Srbiju, Međunarodna organizacija za migracije, Beograd.

- Lukić Vesna (2013): Population Trends in Serbia and the Implications for Settlement System, Forum geografic. Studii și cercetări de geografie și protecția mediului Volume XII(1) pp.67-74.

- Ministry of the Republic of Serbia, Report on Small and Medium Enterprises and Entrepreneurship for 2015, Belgrade, November 2016.

- Mitrović Ljubiša (2014): Uticaj regionalnih nejednakosti u Srbiji na tokove migracija i demografske promene u jugoistočnoj Srbiji, U Ljubiša Mitrović (prir.)Stanovništvo jugoistočne Srbije: regionalne disproporcije u razvoju Srbije, migracije i demografska reprodukcija, (str. 9-30) Niš:Centar za naučnoistraživački rad SANU Univerziteta u Nišu, Filozofski fakultet.

- Panev Goran, Marinković Ivan (2012):Prvi rezultati popisa stanovništva 2011. s posebnim osvrtom na promenu broja stanovnika jugoistočne Srbije, U:Stanovništvo jugoistočne Srbije: uticaj demografskih promena u jugoistočnoj Srbiji na društveni razvoj i bezbednost, (str: 22-43) Niš: Centar za naučna istraživanja SANU i Univerzitet u Nišu.

- Serbia, Foreign Policy and National Security Yearbook Vol.1, Strategic Information and Developments, International Business Publications, USA, Washington DC, USA-Serbia, 2014, p.96

- Stojković Miodrag (1991): Uticaj odnosa sa susednim zemljama na pogranične krajeve Srbije,Geografski problemi pograničnih krajeva Srbije. Beograd: Geografski fakultet PMF. 


\section{RAZVOJNI I BEZBEDONOSNO-GEOPOLITIČKI ASPEKTI DEMOGRAFSKIH PROMENA U JUGOISTOČNOJ SRBIJI}

U radu se razmatraju implikacije demografskih promena u Jugoistočnoj Srbiji na razvoj i bezbednosnu stabilnost., odnosno nestabilnost u Srbiji i na Balkanu. Te demografske promene uslovljene su procesom tranzicije, tačnije, podprocesima koji su njegov integralni deo, a među kojima se, kao najuticajniji u negativnom smislu izdvajaju deindustrijalizacija i stihijski izvedena privatizacija. Primena ovih koncepcija razvoja za kratko vreme je dovela do ekonomske devastacije Srbije, siromašenja njenog stanovništva i produblivinaja regionalnih disproporcija koje su Jugoistočnu Srbiju promovisale kao njen ekonomski i demografski najugroženiji deo.U fokusu analize nalaze se procesi prirodnog i mehaničkog kretanja stanovništva u pograničnim opštinama Jugoistočne Srbije (migracije, starenje i depopulacija), sa posebnim osvrtom na njihov uticaj na razvoj ovih regiona i njihovu geopolitičku stabilnost i perspektivu. Autorka ukazuje na potrebu redefinisanja i ostvarivanja strategije ravnomernog regionalnog razvoja u Srbiji kojom bi se, kroz prioritetne ciljeve, preformulisala politika razvoja pograničnih opština, čime bi se zaustavilo demografsko pražnjenje i podstakao privredni razvoj ovog geoprostora $i$, $u$ isto vreme, očuvao geostrateški demografski balans, kao uslov trajne geopolitičke stabilnosti.

Ključne reči: demografske promene, Jugoistočna Srbija, regionalni razvoj, geopolitička stabilnost, bezbednost. 